Bangladesh J. Sci. Ind. Res. 41(1-2), 1-14, 2006

\title{
Arsenic Removal Efficiencies of a Few Impregnated Silicate Meterials
}

\author{
M. F. Islam and M. Mokhlesur Rahman \\ Department of Applied Chemistry and Chemical Technology \\ University of Rajshahi, Bangladesh
}

\begin{abstract}
The commonly available brick particles were impregnated with selected compounds and tested for As absorption properties. The materials tested are $\mathrm{FeSO}_{4}$ treated roasted brick particles, $\mathrm{Fe}_{2}\left(\mathrm{SO}_{4}\right)_{3}$ treated roasted brick particles, $\mathrm{FeSO}_{4}$ and $\mathrm{Na}_{2} \mathrm{CO}_{3}$ treated brick particles, $\mathrm{Fe}_{2}\left(\mathrm{SO}_{4}\right)_{3}$ and $\mathrm{Na}_{2} \mathrm{CO}_{3}$ treated brick particles, $\mathrm{ZnSO}_{4}$ and $\mathrm{Na}_{2} \mathrm{CO}_{3}$ treated brick particles, $\mathrm{FeSO}_{4}$ and $\mathrm{Na}_{2} \mathrm{HPO}_{4}$ treated brick particles and waste cement plaster as such. It was observed that the substances showed different behavior of As absorption on short and long time contact. On long time contact periods the absorption capacities are much increased with high concentrations of As in solution. However with short time contact with low As concentration, the materials show saturation or no absorption after certain time period. Thus variable capacities for As absorption are shown depending on concentration, time of absorption and interval time between two contact periods.
\end{abstract}

As (III) absorption was studied in the $\mathrm{pH}$ range 2.45-7.0. The data also show that with a contact time of 3 hrs. or more, the level of As is reduced to the acceptable limit of $0.05 \mathrm{ppm}$ in water.

High concentration of phosphate in water decreases as absorption as phosphate is also strongly absorbed by iron oxide impregnated brick particles.

Leaching of loaded arsenic from brick particles using different common chemicals was also studied for ferrous sulfate treated roasted brick particles. Out of the solutions of common chemicals (10\% caustic soda, $20 \%$ sodium chloride, $10 \%$ sodium carbonate, $10 \%$ potassium dihydrogen phosphate, $10 \%$ TSP and $5 \% \mathrm{NH}_{3}$ ) only $10 \%$ caustic soda can leach $95 \%$ As from As loaded brick particles and others much less. Ordinary water within $\mathrm{pH}$ 4-7 leach very little arsenic from iron oxide impregnated brick particles. 


\section{Introduction}

The problem of As contamination in water has inspired many scientists and technologists for the study of substances for the purpose of removal of arsenic from contaminated water. Different systems have been proposed. Out of the several methods, arsenic removal by coagulation and absorption only has assumed importance in view of the applicability in both the industrial and household levels. The coagulation of arsenic contaminated water by alum and ferric chloride is an established method though having difficulties in removing As in different situations. ${ }^{1,2}$ Adsorption methods have assumed importance in view of the reported adsorption properties of different substances for As, such as iron impregnated river sands, green sands and some composite materials. ${ }^{3-6} \mathrm{~A}$ study was initiated in this laboratory on the effectiveness of brick particles (crushed bricks) for removal of arsenic from water after impregnation with iron oxides. This paper reports further work on the As absorption properties of brick particles after modification with selected inorganic compounds and of waste cement plasters as such. By the term silicate materials is understood the commonly available substances in which silica is a major component. the chemistry of the absorption process is yet to be investigated. The purpose of the work was to identify very cheap materials for the making of arsenic filters for the poor. Leaching experiments were done on a selected arsenic absorbed (loaded) material from environmental impact consideration. The effect of the co-existing interfering phosphate ion was also investigated.

\section{Materials and Methods}

\section{Preparation of materials}

For this investigation, ordinary locally made bricks properly burned (first class bricks) and old waste cement plaster were collected and used for study. At first these materials were crushed into small sizes. Of which only $(-3.15+2) \mathrm{mm}$ mesh and $(-2+0.2) \mathrm{mm}$ mesh sizes were taken for experiments. Then the fixed sized crushed bricks and waste silicate materials were treated by the following methods. The chemicals used for treatment are ferruos sulfate, ferric sulfate, zinc sulfate, disodium hydrogen phosphate, sodium carbonate etc.

\section{a) $\mathrm{FeSO}_{4}$ treated roasted brick particles}

200 g crushed brick particles were soaked with freshly prepared $20 \% \mathrm{FeSO}_{4}$ solution for 24 hours. $250 \mathrm{ml}$. solution was used for $200 \mathrm{~g}$ crushed brick. Then the $\mathrm{FeSO}_{4}$ impregnated wet crushed brick particles were taken in a clay pot for heat-treatment in a make shift furnace after draining out excess solution. In this experiment an electric heater of 2 $\mathrm{Kw}$ was used whose surrounding was closed by brick walls with clay as mortar to minimize the loss of heat. A thermometer was used to record the temperature. Soaked crushed brick was heated for three hours at around $450^{\circ} \mathrm{C}-500^{\circ} \mathrm{C}, \mathrm{FeSO}_{4}$ being converted to oxides of iron. This iron oxide impregnated brick particles were used for investiga- 
tion. The thermal decomposition reaction of ferrous sulfate is well known.

\section{b) $\mathrm{FeSO}_{4}$ and $\mathrm{Na}_{2} \mathrm{CO}_{3}$ treated brick particles}

200 g crushed brick particles were soaked with freshly prepared $250 \mathrm{ml}$. of $10 \% \mathrm{FeSO}_{4}$ solution for 24 hours and filtered in order to drain out the excess $\mathrm{FeSO}_{4}$ solution and soaked brick particles were dried in the sun. Then the dried $10 \% \mathrm{FeSO}_{4}$ soaked brick particles were again soaked with $250 \mathrm{ml}$. of $10 \% \mathrm{Na}_{2} \mathrm{CO}_{3}$ solution for 24 hours. Then the brick particles were filtered, washed free of sulfate and dried in the sun. Hydrated ferric and ferrous oxides are formed by the decomposition of unstable ferrous carbonate .

\section{c) $\mathrm{Fe}_{2}\left(\mathrm{SO}_{4}\right)_{3}$ treated roasted brick particles}

$200 \mathrm{~g}$ crushed brick particles were soaked with $250 \mathrm{ml}$. of $10 \% \mathrm{Fe}_{2}\left(\mathrm{SO}_{4}\right)_{3}$ solution for 24 hours and filtered, and dried. It was then heated for an hour and a half using the same electric make shift furnace at temperatures $450^{\circ} \mathrm{C}$. The impregnated brick particles were used for subsequent study. The decomposition of hydrated ferric sulfate is also a well known reaction.

\section{d) $\mathrm{ZnSO}_{4}$ and $\mathrm{Na}_{2} \mathrm{CO}_{3}$ treated brick particles}

200 g crushed brick particles were soaked with $250 \mathrm{ml}$. of $10 \% \mathrm{ZnSO}_{4}$ solution for 24 hours and then filtered, and dried in the sun. Then the $10 \% \mathrm{ZnSO}_{4}$ soaked dried brick particles were soaked with $250 \mathrm{ml}$. of $10 \%$ $\mathrm{Na}_{2} \mathrm{CO}_{3}$ solution for 24 hours and then filtered, washed free of sulfate and dried in the sun. The basic zinc carbonate is formed insitu by the reaction.

$\mathrm{ZnSO}_{4}+\mathrm{Na}_{2} \mathrm{CO}_{3}+\mathrm{H}_{2} \mathrm{O} \longrightarrow \mathrm{ZnCO}_{3}$. $2 \mathrm{Zn}(\mathrm{OH})_{2} \cdot \mathrm{H}_{2} \mathrm{O}+\mathrm{Na}_{2} \mathrm{SO}_{4}$.

\section{e) $\mathrm{Fe}_{2}\left(\mathrm{SO}_{4}\right)_{3}$ and $\mathrm{Na}_{2} \mathrm{CO}_{3}$ treated brick particles}

$200 \mathrm{~g}$ crushed brick particles were soaked with $250 \mathrm{ml}$. of $10 \% \mathrm{Fe}_{2}\left(\mathrm{SO}_{4}\right)_{3}$ solution for 24 hours and then filtered, and dried in the sun. Then the $10 \% \mathrm{Fe}_{2}\left(\mathrm{SO}_{4}\right)_{3}$ soaked brick particles were soaked with $10 \% \mathrm{Na}_{2} \mathrm{CO}_{3}$ solution for 24 hours then filtered, washed free of sulfate and dried in the sun and collected. The hydrated ferric oxide is formed.

\section{f) $\mathrm{FeSO}_{4}$ and $\mathrm{Na}_{2} \mathrm{HPO}_{4}$ treated brick particles}

200 g crushed brick particles were soaked with $250 \mathrm{ml}$. of $10 \% \mathrm{FeSO}_{4}$ solution for 24 hours and then filtered and dried in the sun. Then the $10 \% \mathrm{FeSO}_{4}$ soaked brick particles were again soaked with $250 \mathrm{ml}$. of $10 \%$ $\mathrm{Na}_{2} \mathrm{HPO}_{4}$ solution for 24 hours and then filtered, washed free of sulfate and dried in the sun. Ferrous phosphate is formed insitu by double decomposition.

\section{g) Waste cement plasters}

Waste cement plasters (sand- cement ratio 1:4) were collected and sorted to get the sand cement composite avoiding paint layer or adhering brick splinters. It was crushed to the desired sizes, washed several times with clean water and dried in the oven at $100^{\circ} \mathrm{C}$. 
The $\mathrm{pH}$ of the old waste cement plasterwater mixture was around 7-8 ensuring complete setting of cement. The sand- cement ratio : $1: 4$ ensures proper hardness of the particles.

\section{Analytical}

a) Analysis of prepared materials for Fe content

The finely powdered brick was treated with concentrated hydrochloric acid- hydro fluoric acid mixture $(5: 1)$ for an hour and a half at $95^{\mathrm{O}}$ C. After complete decomposition, the solution obtained was analyzed by colorimetric thiocyanate method for the determination of total iron. Estimation of iron in the waste cement plasters was done after decomposition with concentrated hydrochloric acid only. The data for iron content are given in the Table I.

\section{b) Analysis of arsenic in water}

Water samples were tested for As content by the silver-diethyldithiocarbamate spectro- photometric method using the spectrophotometer ANA-75 (Tokyo Photoelectric Co.). ${ }^{7}$ In the analysis As free $\mathrm{Zn}$ and reagents were used.

\section{c) Analysis of phosphate in water}

The phosphate was determined by ammonium molybdate-hydrazine method. ${ }^{7}$ However instead of K-antimonyl tartrate, Na-K tartrate was used for silicate interference. Satisfactory results obtained. The analysis of all samples (liquids and solids) were done in duplicate and the average is reported.

\section{Absorption tests}

The absorption tests of the materials were made primarily to get information as to the rapidity of the arsenic absorption by the materials from water solutions and the capacity of the materials for arsenic absorption. The rapidity of the absorption process is expected to vary for different materials. The capacity of the materials for arsenic uptake from water determines the volume of water treatable by these materials. Both these

Table I. Data for iron content in chemically treated and untreated crushed brick particles and waste cement plasters.

\begin{tabular}{c|c}
\hline Arsenic absorbing materials & Percentage of iron content \\
\hline Brick particles & 4.75 \\
$\mathrm{FeSO}_{4}$ treated roasted brick particles & 10 \\
$\mathrm{Fe}\left(\mathrm{SO}_{4}\right)_{3}$ treated roasted brick particles & 7.0 \\
Waste cement plasters & 1.37 \\
$\mathrm{ZnSO}_{4}$ and $\mathrm{Na}_{2} \mathrm{CO}_{3}$ treated brick particles & 6.6 \\
$\mathrm{Fe}_{2}\left(\mathrm{SO}_{4}\right)_{3}$ and $\mathrm{Na}_{2} \mathrm{CO}_{3}$ treated brick particles & 8.0 \\
$\mathrm{FeSO}_{4}$ and $\mathrm{Na}_{2} \mathrm{HPO}_{4}$ treated brick particles & 7.0 \\
\hline
\end{tabular}


factors are important for the actual design of arsenic filters. The actual capacity may not be obtained in a short time test. The ultimate capacity may be dependent on the concentration of arsenic in water, the equilibration time and also the interval time especially for the iron-oxide impregnated particles. Tests were performed to determine the short time and long time capacity for the materials. Test solutions were $1.0 \mathrm{ppm}$ As (III) and $4.0 \mathrm{ppm}$ As (III) which are much higher than the arsenic concentration encountered in ground water. Very high concentration was used for long time capacity tests. Capacity is expressed as As absorbed per kg of the materials. Only As (III) solutions are used in the absorption experiments as ground water contain larger proportion of As (III). The loading of the materials with arsenic is similar in principle to the determination of the capacity of ion-exchangers.

\section{a) Time dependence of arsenic absorption by the materials}

$20 \mathrm{~g}$ of $(-3.15+2) \mathrm{mm}$ and $20 \mathrm{~g}$ of $(-2+0.2) \mathrm{mm}$ mesh size materials were taken separately in same size glass beakers respectively and washed with distilled water to remove all fine particles and dust. After complete drainage of adhering water, the material was immersed in $100 \mathrm{ml}$. of $1.0 \mathrm{ppm}$ As (III) prepared solution $(\mathrm{pH}=6.5)$. The mixture of materials and solution was agitated by an electric stirrer avoiding high stirring speed. After the first tweenty minutes stirring, $10 \mathrm{ml}$. of As solution was withdrawn and arsenic concentration of the solution was determined by SDDC method. ${ }^{7}$ This test process was repeated after the 2nd $20 \mathrm{~min}$., 3rd $20 \mathrm{~min}$., 4th $20 \mathrm{~min}$. , 5th $20 \mathrm{~min}$. and 6th $20 \mathrm{~min}$. for the total absorption period of 120 minutes. The different portions were analysed for As concentration. The total As absorption was determined. Fig. 1 and 2 indicate the time dependence of absorption of As of the materials.

b) Ultimate absorption capacity of the materials for short time arsenic absorption at moderately high arsenic concentration for short interval time between consecutive absorption tests

The selected sizes of prepared $20 \mathrm{~g}$ materials were taken in different beakers and $100 \mathrm{ml}$. of $4.0 \mathrm{ppm}(\mathrm{pH}=3.45)$ As (III) prepared solution was added in each beaker for each experiment. The individual prepared mixture of material and As (III) solution were agitated by an electric stirrer avoiding high stirring speed. After the first 1.0 hour stirring, As (III) solution was withdrawn for the determination of As concentration. After the 1.0 hour absorption, the remaining As solution filtered out and the materials were dried in the air for the next experiment. After the 1.0 hour interval time, fresh $100 \mathrm{ml}$. of $4.0 \mathrm{ppm}$ As (III) solution added to the material and stirred as before for 1.0 hour. This process was repeated consecutively for the 3rd $1.0 \mathrm{hr}$ to 12 th 1.0 hr. period, each time a portion of solution being withdrawn for analysis maintaining the interval time between two absorption experiments at 1.0 hour. The different portions of solution were analysed for As concentration. 
Amount of arsenic absorbed by the material in each time period was calculated from the change in As concentration. The maximum cumulative absorption capacity for As (III) per $\mathrm{kg}$ of materials was determined. The cumulative amount of arsenic absorbed after the 12th $1 \mathrm{hr}$. period is given for the two sizes of the materials Tabel II.

c) Ultimate absorption capacity of the materials for long time arsenic absorption and long Interval time between two consecutive experiments for different very high arsenic concentration.

Experimental procedure is same as before, but $40.0 \mathrm{ppm}(\mathrm{pH}=3.40), 120 \mathrm{ppm}$
$(\mathrm{pH}=3.25)$ and $200 \mathrm{ppm}(\mathrm{pH}=3.08)$ of As (III) prepared solution was used. Absorption period was 64 hours and interval time between two consecutive experiments was 24 hours. For each experiment different portions of solution were analysed as before for As concentration and maximum absorption capacity of the materials for As (III) per kg material was calculated Table II.

\section{d) Effect of phosphate in water}

Phosphate may be present in tube well water. Therefore to observe the effect of phosphate on arsenic absorption by the material, the test (a) was repeated with solution of As (III)

Table II. Ultimate absorption capacities for As (III) of different materials under different loading conditions

\begin{tabular}{|c|c|c|c|c|}
\hline \multirow{3}{*}{ Materials } & \multicolumn{2}{|c|}{$\begin{array}{l}\text { Short time absorption, interval time } \\
1.0 \mathrm{hr} \text {., moderate As concentrations. } \\
\mathrm{pH}=3.45\end{array}$} & \multicolumn{2}{|c|}{$\begin{array}{c}\text { Long time absorption, } \\
24 \text { hrs. interval,high As concentra- } \\
\text { tions. } \mathrm{pH}=2.45\end{array}$} \\
\hline & \multicolumn{2}{|c|}{ Capacity=gmAs/kg materials } & \multicolumn{2}{|c|}{ Capacity=gm As/kg materials } \\
\hline & $\begin{array}{c}(-3.15+2) \mathrm{mm} \\
\text { mesh size }\end{array}$ & $\begin{array}{l}(-2+0.2) \mathrm{mm} \\
\text { mesh size }\end{array}$ & $\begin{array}{c}(-3.15+2) \mathrm{mm} \\
\text { mesh size }\end{array}$ & $\begin{array}{l}(-2+0.2) \mathrm{mm} \\
\text { mesh size }\end{array}$ \\
\hline $\begin{array}{l}\mathrm{FeSO}_{4} \text { treated roasted } \\
\text { brick particles }\end{array}$ & 0.1131 & 0.098 & 0.926 & 0.844 \\
\hline $\begin{array}{l}\mathrm{Fe}\left(\mathrm{SO}_{4}\right)_{3} \text { treated } \\
\text { roasted brick particles }\end{array}$ & 0.097 & 0.086 & 0.749 & 0.556 \\
\hline $\begin{array}{l}\mathrm{ZnSO}_{4} \text { and } \mathrm{Na}_{2} \mathrm{CO}_{3} \\
\text { treated brick particles }\end{array}$ & 0.0862 & 0.073 & 0.693 & 0.546 \\
\hline $\begin{array}{l}\mathrm{FeSO}_{4} \text { and } \mathrm{Na}_{2} \mathrm{CO}_{3} \\
\text { treated brick particles }\end{array}$ & 0.0955 & 0.0855 & 0.818 & 0.556 \\
\hline $\begin{array}{l}\mathrm{Fe}_{2}\left(\mathrm{SO}_{4}\right)_{3} \text { and } \mathrm{Na}_{2} \mathrm{CO}_{3} \\
\text { trated brick particles }\end{array}$ & 0.0702 & 0.060 & 0.787 & 0.584 \\
\hline $\begin{array}{l}\mathrm{FeSO}_{4} \text { and } \mathrm{Na}_{2} \mathrm{HPO}_{4} \\
\text { treated brick particles }\end{array}$ & 0.064 & 0.0597 & 0.773 & 0.574 \\
\hline
\end{tabular}


with different amounts of phosphate in the mixed solution for absorption by $(-3.15+2)$ mm mesh $\mathrm{FeSO}_{4}$ treated roasted brick particles. The aliquots were analysed for As and phosphate concentration for the total As and phosphate absorption from the aqueous phase at predetermined time intervals. The amount of As and phosphate absorbed after 120 minutes total time are given in Table III for the $\mathrm{FeSO}_{4}$ treated roasted brick particles only.

Leaching of absorbed As (III) by different reagents

The following experiments were performed to find out the effect of commonly used chemicals on the As absorbed brick particles.
Principally leaching experiments were done on the As absorbed brick as to predict any possible leaching of As in the environment and the possibility of recovery of As from brick particles. The commonly used chemicals that may be encountered in the field conditions are $\mathrm{Na}_{2} \mathrm{CO}_{3}$ used as washing soda, $\mathrm{NaCl}$ used always in the domestic environment, TSP and $\mathrm{KH}_{2} \mathrm{PO}_{4}$ may be used as fertilizer in the village lands. Their action on As absorbed brick sands is useful for predicting for possible environmental impacts. Also the strong alkali was used for possible As recovery from arsenic loaded brick particles.

$20 \mathrm{~g}$ of $(-3.15+2) \mathrm{mm}$ mesh As loaded material were taken in different beakers. Then

Table III. Arsenic absorption by $\mathrm{FeSO}_{4}$ treated roasted brick particles in absence and in presence of low and high concentration of phosphate in water

Weight of brick particles taken $=20 \mathrm{~g}$

Size $=(-3.1+2) \mathrm{mm}$ mesh

Volume of solution taken for absorption $=100 \mathrm{ml}$.

Initial As content in solution $=1.0 \mathrm{ppm}$

Initial phosphate contents in solution $=0.0 \mathrm{ppm}, 6.0 \mathrm{ppm}$ and $10.0 \mathrm{pmn}$.

\begin{tabular}{|c|c|c|c|c|c|c|c|}
\hline \multirow{2}{*}{$\begin{array}{c}\text { Absorbing } \\
\text { material }\end{array}$} & \multirow[b]{2}{*}{$\begin{array}{l}\text { Phosphate } \\
\text { concen- } \\
\text { tration in } \\
\text { solution } \\
\text { (ppm) }\end{array}$} & \multirow{2}{*}{$\begin{array}{l}\text { Absorpti } \\
\text { on } \\
\text { period } \\
\text { minutes }\end{array}$} & \multicolumn{3}{|c|}{ For arsenic absorption } & \multicolumn{2}{|c|}{ For Phosphate absorption } \\
\hline & & & \begin{tabular}{|c|} 
As content \\
in solution \\
after \\
absorption \\
(ppm)
\end{tabular} & $\begin{array}{l}\text { Total \% of } \\
\text { As } \\
\text { absorption } \\
\text { from } \\
\text { solution }\end{array}$ & $\begin{array}{c}\text { Total As } \\
\text { absorption } \\
\text { (mgm As/ } \\
\text { kg brick } \\
\text { sands) }\end{array}$ & $\begin{array}{c}\text { Phosphate } \\
\text { concentration in } \\
\text { solution after } \\
\text { absorption } \\
\text { (ppm) }\end{array}$ & $\begin{array}{l}\text { Percentage } \\
\text { phosphate } \\
\text { absorption }\end{array}$ \\
\hline $\begin{array}{l}\mathrm{FeSO}_{4} \\
\text { treated }\end{array}$ & 0.00 & 120 & 0.02 & 98 & 4.9 & - & - \\
\hline $\begin{array}{c}\text { roasted } \\
\text { brick }\end{array}$ & 6.00 & 120 & 0.04 & 96 & 4.8 & 0.0 & 100 \\
\hline particles & 10.00 & 120 & 0.16 & 84 & 4.2 & 0.0 & 100 \\
\hline
\end{tabular}




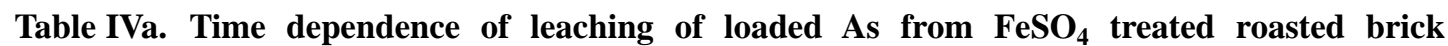
particles with $\mathrm{NaOH}$ solution

Weight of brick particles taken in a beaker $=20 \mathrm{~g}$

Size of the brick particles taken $=(-3.15+2) \mathrm{mm}$ mesh

Concentration of the leaching solution $=10 \% \mathrm{NaOH}$

Volume of solution taken for leaching of As $=100 \mathrm{ml}$.

$\mathrm{pH}$ of the solution $=14.0$

\begin{tabular}{c|c|c|c|c}
\hline Absorbing material & $\begin{array}{c}\text { Leaching period } \\
\text { (minutes) }\end{array}$ & $\begin{array}{c}\text { Actual As } \\
\text { concentration in } \\
\text { leach (ppm) }\end{array}$ & $\begin{array}{c}\text { Total amount of As } \\
\text { in brick particles, } \\
\text { g (in 20 g) }\end{array}$ & $\begin{array}{c}\text { \% leached As in } \\
\text { solution }\end{array}$ \\
\hline FeSO $_{4}$ Treated & 20 & 85.0 & & 50.35 \\
roasted brick & 60 & 105.0 & $168.8 \times 10^{-4}$ & 62.20 \\
& 10 & 135.0 & & 79.97 \\
& 120 & 160.0 & & 94.78 \\
& 160.0 & 160.0 & & 94.78 \\
\hline
\end{tabular}

Table IVb. Leaching of loaded As from $\mathrm{FeSO}_{4}$ treated roasted brick particles using TSP (Triple Super Phosphates) solution

Weight of brick particles taken in a beaker $=9 \mathrm{~g}$

Size of the brick particles taken $=(-3.15+2) \mathrm{mm}$ mesh

Concentration of the leaching solution $=10 \% \mathrm{TSP}$

Volume of solution taken for leaching of As $=100 \mathrm{ml}$.

$\mathrm{pH}$ of the solution $=2.97$

\begin{tabular}{c|c|c|c|c}
\hline Absorbing material & $\begin{array}{c}\text { Leaching period } \\
\text { (minutes) }\end{array}$ & $\begin{array}{c}\text { Actual As } \\
\text { concentration in } \\
\text { leach (ppm) }\end{array}$ & $\begin{array}{c}\text { Total amount of As } \\
\text { in brick particles, } \\
\text { g (in 20 g) }\end{array}$ & $\begin{array}{c}\text { \% leached As in } \\
\text { solution }\end{array}$ \\
\hline FeSO 4 Treated & 20 & 2.5 & & 3.29 \\
roasted brick & 60 & 3.0 & $75.96 \times 10^{-4}$ & 6.58 \\
& 100 & 7.5 & & 9.87 \\
& 120 & 26.25 & & 34.56 \\
\hline
\end{tabular}


$100 \mathrm{ml}$. each of $10 \% \mathrm{NaOH}, 20 \% \mathrm{NaCl}$, $10 \% \mathrm{Na}_{2} \mathrm{CO}_{3}, 10 \% \mathrm{KH}_{2} \mathrm{PO}_{4}, 10 \%$ TSP and $5 \% \mathrm{NH}_{3}$ was added to each beaker for each experiment. The mixture of arsenic loaded materials and added leaching solution was agitated by an electric stirrer.

After the first 20 min stirring $2.0 \mathrm{ml}$ of the solution was withdrawn to determine As concentration in leach solution. This process was repeated for the consecutive 20 minutes for the total time of 120 minutes. After total 120 minutes leaching the actual As in leached solution was determined and the \% As leached was calculated. Out of the chemicals used for leaching studies, detailed data for the $\mathrm{NaOH}$ and TSP only are given in the Table IVa and Table IVb for iron oxide impregnated brick particles. Leaching data for other common reagents are given in abbreviated form in Table V.

\section{Results and Discussion}

It is observed from the Figs. 1 and 2 that minute quantities of As in water or solution may be absorbed by untreated ordinary brick particles and ordinary waste cement plasters, but absorption process is very slow for brick suggesting that ordinary brick is unsuitable for absorption arsenic from water or solution but waste cement plasters is much more suitable. After 2 hours absorption period the untreated ordinary brick particles reduced arsenic level to $0.20 \mathrm{ppm}$ As from $1.0 \mathrm{ppm}$ As solution whereas waste cement plasters reduced it to zero ppm As from $1.0 \mathrm{ppm}$ As solutionin the same time period. The experiments showed that bricks should be modified chemically to enable them to act as absorber for As from water or solution and waste plasters can be used for arsenic removal as such. The arsenic absorption properties of cement composites is also reported recently. ${ }^{8}$

It was found that the absorption process is much faster for the modified brick particles. After 120 minutes absorption period As concentration in aqueous solution was down to the permissible limit of $0.05 \mathrm{ppm}$. It can be concluded that Fe-impregnated bricks are more active to absorb arsenic from water or solution than the ordinary bricks because of higher iron content (10\% Fe). The increase of iron content in materials also increase As absorption capacity of the materials. This phenomenon suggests that the absorption of As by impregnated materials may occur by adsorption or chemisorption process at the surfaces of the particles and pores in the body of materials where oxides may be deposited. It is seen that rapid absorption is observed for the first 20 minutes and after that the absorption process is slowed. Almost $80 \%$ As is absorbed in the first 20 minutes. More time is necessary to decrease the level of As to less than $0.05 \mathrm{ppm}$. The phenomena can be explained by assuming that in the initial period the arsenic is absorbed by the surface deposited oxides and hydroxides and in the later period the As ions has to diffuse to the interior of the particles. The results obtained for different sizes of materials are shown graphically. The sizes selected for the study give almost the same level of arsenic (III) absorbing capability for single contact. However the absorption properties of zinc hydroxide impregnated brick particles are 


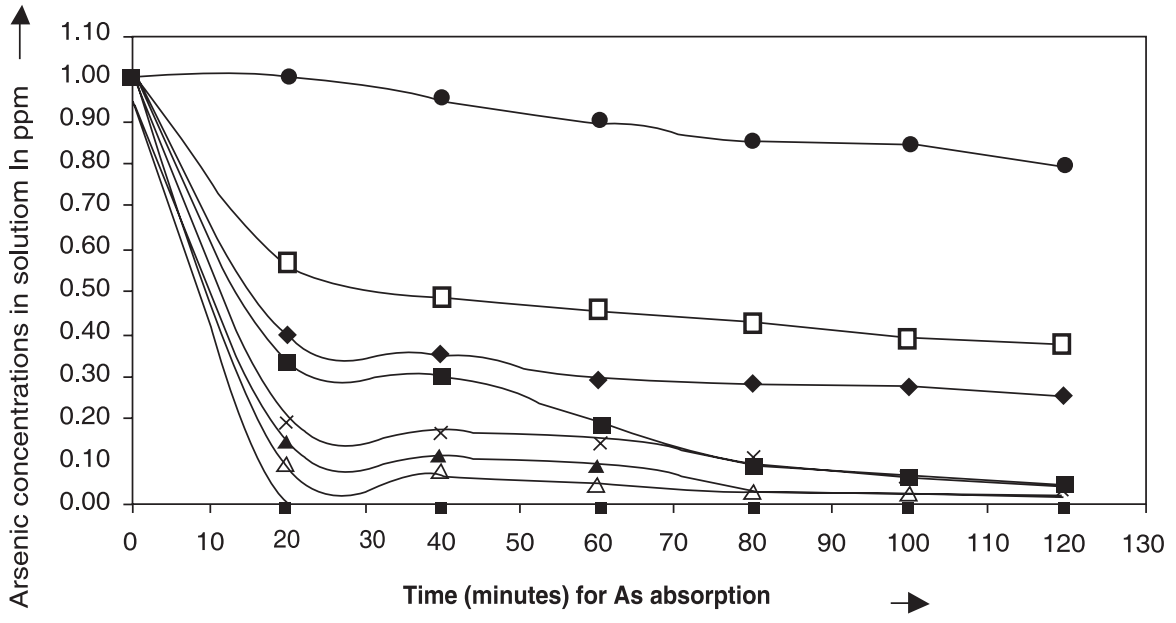

$$
\begin{array}{ll}
\rightarrow-\text { Fresh ordinary brick particles } & -\mathrm{FeSO}_{4} \text { treated roasted brick } \\
\triangle-\mathrm{Fe}_{2}\left(\mathrm{SO}_{4}\right)_{3} \text { treated roasted brick particles } & \leftarrow \mathrm{ZnSO}_{4} \text { and } \mathrm{Na}_{2} \mathrm{CO}_{3} \text { treated brick } \\
\rightarrow-\mathrm{FeSO}_{4} \text { and } \mathrm{Na}_{2} \mathrm{CO}_{3} \text { treated brick } & \rightarrow-\mathrm{Fe}_{2}\left(\mathrm{SO}_{4}\right)_{3} \text { and } \mathrm{Na}_{2} \mathrm{CO}_{3} \text { treated brick particles } \\
\square-\mathrm{FeSO}_{4} \text { and } \mathrm{Na}_{2} \mathrm{HPO}_{4} \text { treated brick } & -- \text { Waste cement plasters }
\end{array}
$$

Fig. 1. Variation of As absorption by different materials $[(-3.15+2) \mathrm{mm}$ mesh size], with time.



$$
\begin{array}{ll}
\rightarrow-\text { Fresh ordinary brick particles } & -\mathrm{FeSO}_{4} \text { treated roasted brick } \\
\triangle-\mathrm{Fe}_{2}\left(\mathrm{SO}_{4}\right)_{3} \text { treated roasted brick } & -\mathrm{ZnSO}_{4} \text { and } \mathrm{Na}_{2} \mathrm{CO}_{3} \text { treated brick } \\
\rightarrow-\mathrm{FeSO}_{4} \text { and } \mathrm{Na}_{2} \mathrm{CO}_{3} \text { treated brick } & \rightarrow-\mathrm{Fe}_{2}\left(\mathrm{SO}_{4}\right)_{3} \text { and } \mathrm{Na}_{2} \mathrm{CO}_{3} \text { treated brick } \\
\square-\mathrm{FeSO}_{4} \text { and } \mathrm{Na}_{2} \mathrm{HPO}_{4} \text { treated brick } & \rightarrow-\text { Waste cement plasters }
\end{array}
$$

Fig. 2. Variation of As absorption by different materials $[(-2+0.2) \mathrm{mm}$ mesh size], with time. 
almost similar to the iron oxide impregnated brick whereas iron phosphate impregnated brick particles has lower ability of arsenic absorption. Impregnation with iron hydroxide by ferrous sulfate-sodium carbonate treatment is much less effective. The better absorption capability is shown by the ferrous and ferric sulfate impregnated roasted brick particles than the iron phosphate impregnated.

For 120 minutes absorption period, arsenic absorbed from low As concentration (1.0 ppm) solution by materials are given below for the given $\mathrm{pH}$ value in a single contact.
Ultimate absorption capacity of the materials for short and long time arsenic absorption at moderate to high arsenic concentration.

The absorption properties of the materials for longer time use in particular conditions may be different. It was found that for treated bricks the absorption properties, specially the capacity, is dependent on the total time of contact and the concentration of As level. Single contact does not show the real capacity of the materials for arsenic absorption. The previous experiment does not show the real capacity as the material will again absorb

\begin{tabular}{l|c|c}
\hline \multicolumn{1}{c|}{$\begin{array}{c}\text { Materials brick } \\
\text { particles }\end{array}$} & $\begin{array}{l}\text { Total amount of absorbed As for (- } \\
3.15+2) \mathrm{mm} \text { mesh brick particles. } \\
(\mathrm{mg} \mathrm{As} / \mathrm{kg} \text { brick sands) } \mathrm{pH}=6.5\end{array}$ & $\begin{array}{l}\text { Total amount of absorbed As for } \\
(-2+0.2) \\
\text { (mg As/kg brick sands) } \mathrm{pH}=6.5\end{array}$ \\
\hline Untreated ordinary brick particles & 1.0 & 0.35 \\
$\mathrm{FeSO}_{4}$ treated roasted & 4.8 & 4.75 \\
$\mathrm{Fe}_{2}\left(\mathrm{SO}_{4}\right)_{3}$ treated roasted & 4.9 & 4.75 \\
$\mathrm{ZnSO}_{4}$ and $\mathrm{Na}_{2} \mathrm{CO}_{3}$ treated & 4.7 & 4.675 \\
$\mathrm{FeSO}_{4}$ and $\mathrm{Na}_{2} \mathrm{CO}_{3}$ treated & 4.7 & 4.67 \\
$\mathrm{Fe}_{2}\left(\mathrm{SO}_{4}\right)_{3}$ and $\mathrm{Na}_{2} \mathrm{CO}_{3}$ treated & 3.725 & 3.575 \\
$\mathrm{FeSO}_{4}$ and $\mathrm{Na}_{2} \mathrm{HPO}_{4}$ treated & 3.1 & 3.025 \\
\hline
\end{tabular}

Thus impregnation with iron oxides increases the absorption capacities of ordinary brick particles by 4-5 times. However the rates of As absorption in the initial 20 minutes determines the rapidity of As removal. In this regard zinc treated and the iron sulfate treated and roasted brick particles are much faster. However the maximum absorption is not achieved in a single contact as shown latter. arsenic from water if contacted with fresh arsenic solution showing the same time dependence. It was also observed that the interval time between two contacts also influences the total capacity of absorption of arsenic. In the short tine contact the interval was fixed at 1 hour and in the long time contact the interval time was 24 hours.

\section{Short time absorption}

Data show that after 7 hours or more total absorption time, the materials absorbed max- 
imum As and this was the maximum absorption capacity of the materials in the short time contact with 1 hour interval condition. Capacity was determined in terms of As absorbed per kg of materials. The experimental data showed that almost $50 \%$ of the total capacity was used up in the first 3 contacts. There after slow absorption occurred in the subsequent periods.

\section{Long time arsenic absorption}

The effect on the maximum As absorption capacity of the materials for long time As absorption period and very long interval time between two consecutive absorption of As from solution was investigated.

The reason for such study is that As absorption process may be totally different involving not the surface only, but also the total mass of the particles with its internal pores. Longer contact time and longer interval time between two contacts together with higher As concentration make available the internal pores of the particles for As absorption. It was thought that such experimental conditions will give necessary time and driving force for the utilization of unused pores for the As absorption. Moreover unknown chemisorptions process may also take place in long time contact. Longer interval time may give time for the diffusion of surface absorbed species to migrate to internal pores of the materials. The active materials is expected to be deposited in the pores of the brick particles that should have very large pore surface.

From the data Table II it is observed that after 256 hours absorption period the material was fully loaded with As and after the 4th 64 hour absorption period the material did not absorb any more arsenic from solution. Cumulative maximum absorption capacity was determined in terms of As absorbed per kg of the material. It is evident that ultimate absorption capacity can be reached only with longer contact time. The ultimate capacity is almost 10 times greater for the larger particle size for long time contact and long interval time for the $\mathrm{pH}$ range used for the solutions.

\section{Effect of phosphate}

The phosphate ion and arsenate/ arsenite ion coexist in many ground water. In some places phosphate may be present in concentrations much higher than the arsenic concentration. It is necessary to see the effect of high concentration of phosphate on arsenic absorption. Such tests were done only on iron oxide impregnated brick particles using ferrous sulfate. The effect of $0.0 \mathrm{ppm}, 6.0 \mathrm{ppm}$ and $10.0 \mathrm{ppm}$ of phosphate in solution on arsenic absorption is shown Table III. The data clearly indicates the competing effect of phosphate in the absorption process. The higher relative absorption of phosphate fro mixed solution is shown from the iron oxide impregnated brick.

The effect is shown graphically in Fig. 3. It may be predicted that the presence of high concentration of phosphate in water or solution will decrease arsenic absorption capacity of the materials for long time use. Thus the filters designed for arsenic removal is not expected to run properly in areas where the ground water phosphate concentration is high as phosphate will soon saturate the 


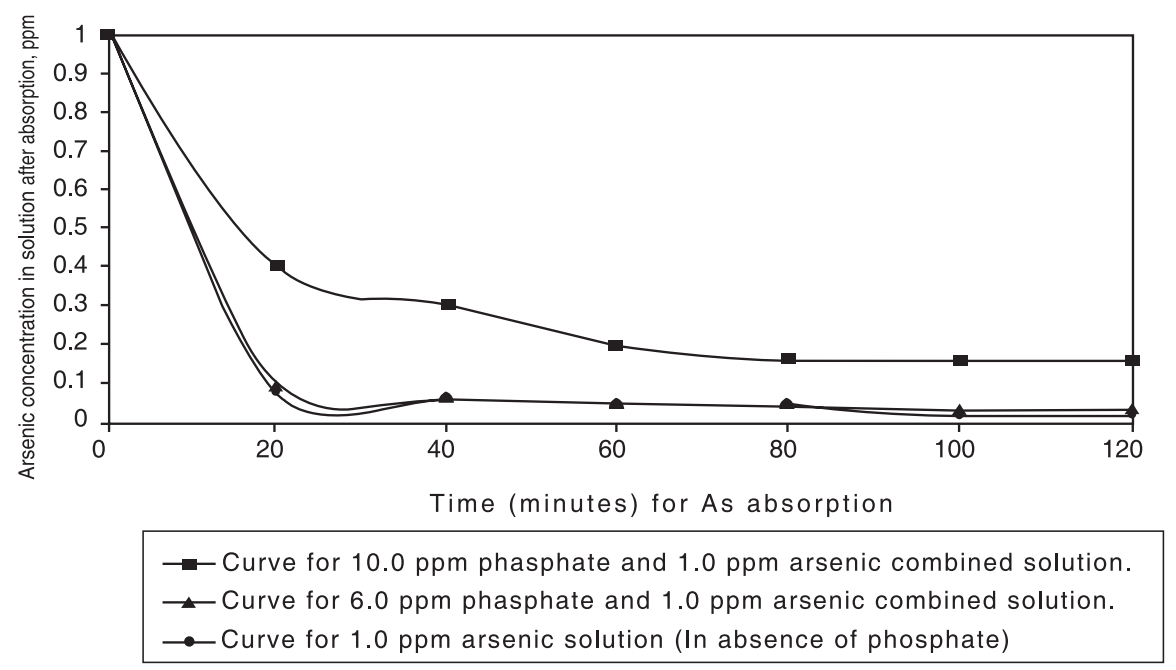

Fig. 3. Effect of phosphate concentration on As absorption

absorbing material in view of the greater affinity of the phosphate. However as iron phosphate impregnated brick prticles also absorb Arsenic (III) from water, an equilibrium condition may establish with arsenic and phosphate in solid and liquid.

\section{Leaching of absorbed as by different reagents}

The results indicate that only $10 \% \mathrm{NaOH}$ is able to leach out $~ 95 \%$ of As in the brick sands (Table IV and V). Others are not effective to leach out even $20 \%$ of the total As absorbed by using high concentration of reagent. However $10 \%$ TSP can leach out up to about $35 \%$. Ordinary water in two $\mathrm{pH}$ ranges leach very little arsenic from the loaded brick particles.

The results indicate that the arsenic is bound very strongly to the iron oxide impregnated brick particles indicating strong bond formation with the material. Thus waste arsenic loaded brick particles do not pose any threat
Table V. Maximum \% leaching of absorbed as from the brick particles

\begin{tabular}{c|c}
\hline Chemicals & Maximum \% leached As \\
\hline $10 \% \mathrm{NaOH}$ solution & 94.78 \\
$20 \% \mathrm{NaCI}$ solution & 17.28 \\
$10 \% \mathrm{Na}_{2} \mathrm{CO}_{3}$ solution & 18.36 \\
$10 \% \mathrm{KH}_{2} \mathrm{PO}_{4}$ & 11.85 \\
$10 \% \mathrm{TSP}_{\text {solution }}$ & 34.56 \\
$5 \% \mathrm{NH}_{3}$ solution & 29.62 \\
$\mathrm{H}_{2} \mathrm{O}$ & $(\mathrm{pH}=4) 3.0$ \\
& $(\mathrm{pH}=7) 5.0$ \\
\hline
\end{tabular}

to the environment as very little of the reagents are present in the environment especially in the rural areas. Only negligible quantities may be leached in the environment but the concentration of leached arsenic will be much less than the arsenic in the tube well water. Studies were not made for other arsenic loaded materials but effects are expected to be similar for iron compound impregnated materials. 


\section{Conclusion}

The experimental data show that the impregnated brick particles and sand-cement composites have excellent arsenic absorption properties from water. Ordinary bricks and cement are in effect silicate materials manufactured from clay. Impregnation with non toxic iron and zinc compounds enhances the arsenic absorption properties of brick particles. However the iron oxide impregnation may be a cheaper process than that with zinc oxide. It seems higher iron oxide percentage favor more As (III) absorption. As (V) absorption is expected to be more favorable as literature reports better removal with other iron containing materials for the higher oxidation state of arsenic. Besides the arsenic absorption capacity the kinetics of absorption and leaching characteristics suggest the suitability of iron oxide impregnated materials for practical filters. The other impregnated materials have to be studied more for practical use. The chemistry of the arsenic absorption process remains to be investigated. However a chemisorptions mechanism is more likely for iron oxide impregnated brick materials in view of the difficult leaching of arsenic from the arsenic loaded material.

\section{References}

1. J. G. Hering, P. Y. Chen, J. A. Wilkie, M. Elimelech and S. Liang. Arsenic removal by ferric chloride. Journal American Water Works Association, 88(4) (1996) 155-167.
2. J. G. Hering, P. Y. Chen, J. A. Wilkie, M. Elimelech and S. Liang. Arsenic removal from drinking water during coagulation. Journal of Environmental Engineering, 123(8) (1996) 800-807.

3. R. C. Vaishya and I. C. Agarwal. Removal of Arsenic (III) from contanminated ground waters by Ganga sand. Journal of Indian Water Works Association, 25(3) (1993) 249-253.

4. A. Joshi and M. Chaudhuri. Removal of arsenic from ground water by iron-oxidecoated sand. J. Environ. Eng. (N.Y), 122(8) (1996) 769-771.

5. K. S. Subramanian, T. Viraraghavan, T. Phommavong and S. Tanjore. Manganese greensand for removal of arsenic in drinking water. Water Quality Research Journal of Canada, 32(3) (1997) 551-561.

6. J. Hlavay, K. Foldi-Polyak, J. Inczedy. Application of new adsorbent for removal of arsenic from drinking water. (Chem. Prot, Envioon. 1987) 119-30 (Eng.)

7. A. D. Eaton, L. S. Clesceri, A, E. Greenberg. Standard Methods for the Examination of Water and Wastewater. 19th Ed. 1995.

8. S. Kundu, A. Pal, SK Ghosh, M. Mandal and T. Pal. Removal of arsenic from water using hardened paste of Portland cement. Environ. Technol, 25(3) (2004) 301-9. 